\section{INVESTIGATION ON DOWNSTREAM PROCESSING OF INDUSTRIAL SCALE OF FLEXIRUBIN PRODUCTION USING SUPERPRO DESIGNER}

Muhammad Zainuddin Arriafdia, Mohd Helmi Sanib, Wan Azlina Ahmadb, Muhd Nazrul Hisham Zainal Alama*

aDepartment of Bioprocess and Polymer Engineering, School of Chemical and Energy Engineering, Universiti Teknologi Malaysia, 81310 UTM Johor Bahru, Johor, Malaysia

bFaculty of Science, Universiti Teknologi Malaysia, 81310 UTM Johor

Bahru, Johor, Malaysia
Article history

Received

22 February 2020

Received in revised form

6 December 2020

Accepted

5 January 2021

Published online

23 February 2021

*Corresponding author nazrulhisham@utm.my

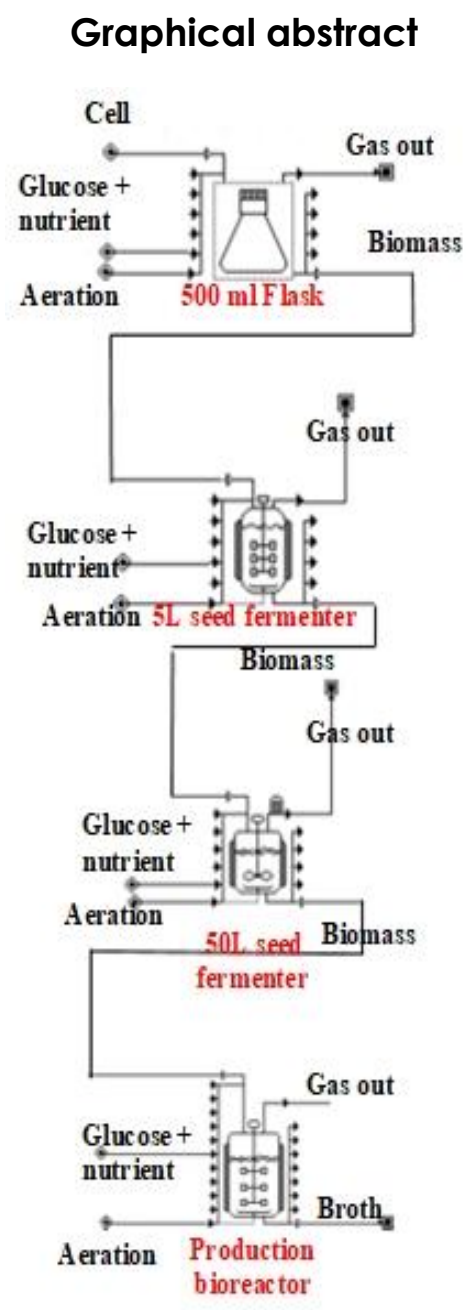

\begin{abstract}
The aim of this work is to utilize a process simulator SuperPro Designer v5.5 (Intelligent, NJ, USA) for investigation on the most optimum scenario for the recovery of flexirubin pigment that was produced from a fermentation process using Chryseobacterium artocarpi strain. Process flow sheeting was based on the production of $300 \mathrm{~kg}$ per annum of flexirubin. Production phase at $1000 \mathrm{~L}$ bioreactor (including steps for the inoculum development) and different scenarios/routes for recovery of flexirubin were considered. SuperPro designer process simulator allowed for the computation of overall operating cost and capital cost under various operating parameters. Results from simulation shows that all proposed downstream processing routes is capable of achieving a high degree of flexirubin recovery yield i.e. at least $94 \%$ (or greater). Operating cost was relatively low as the overall quantity of flexirubin was rather small. Capital cost for equipment purchasing however highly depending on the selection of unit procedures for recovery of flexirubin. Centrifugation unit accelerated the separation processes but it is costly compared to the dead-end filtration unit. The latter was found to be the bottleneck for the optimization step where high yield of flexirubin can be warranted at reduced capital cost by at least $40 \%$.
\end{abstract}

Keywords: Fermentation, SuperPro Designer, flexirubin, downstream processing

\begin{abstract}
Abstrak
Tujuan kerja ini adalah menggunakan perisian SuperPro Designer v5.5 (Intelligent, NJ, USA) untuk menyiasat senario paling optimum untuk pemulihan pigmen flexirubin yang dihasilkan daripada proses penapaian menggunakan Chryseobacterium artocarpi. Aliran proses berdasarkan pengeluaran flexirubin sebanyak $300 \mathrm{~kg}$ setahun. Fasa pengeluaran dipertimbangkan pada $1000 \mathrm{~L}$ bioreaktor (termasuk langkah untuk pembangunan inokulum) dan senario / laluan yang berbeza bagi pemulihan flexirubin. SuperPro juga diaplikasikan dalam kos pengiraan operasi keseluruhan dan kos modal di bawah pelbagai parameter operasi. Keputusan dari simulasi menunjukkan bahawa semua laluan pemprosesan yang dicadangkan mampu mencapai tahap pemulihan flexirubin yang tinggi iaitu sekurang-kurangnya $94 \%$ (atau lebih besar). Kos operasi adalah rendah kerana jumlah keseluruhan flexirubin agak kecil. Kos modal untuk pembelian peralatan bagaimanapun sangat bergantung pada pemilihan prosedur unit untuk pemulihan flexirubin. Unit sentrifugasi mempercepatkan proses pemisahan tetapi ia mahal
\end{abstract}


berbanding dengan unit penapisan mati. Yang terakhir ini dijumpai sebagai hambatan untuk langkah pengoptimuman di mana hasil flexirubin yang tinggi dapat dijamin dengan biaya modal yang dikurangkan sekurang-kurangnya $40 \%$.

Kata kunci: Penapaian, SuperPro Designer, pengoptimuman, hiliran

(c) 2021 Penerbit UTM Press. All rights reserved

\subsection{INTRODUCTION}

Flexirubin is a yellowish-orange pigment (colorant) that can be biologically produced using a Chryseobacterium genus bacteria through a fermentation processes [1]. Aside from being a potential alternative to synthetic colorants, flexirubin can also be utilized in the treatment for chronic skin disease, eczema, gastric ulcers etc. [2]. Investigation on the yield of flexirubin production via aerobic fermentation processes has been carried out in lab and pilot scale operation [3]. Optimal growth conditions for a batch fermentation of $C$. artocarpi in a bioreactor were found to be at temperature of $30^{\circ} \mathrm{C}, \mathrm{pH} 7$ and at mild aeration and agitation rates of 0.1 - 0.2 v.v.m and 200 rpm, respectively [4]. Cultivation was carried out for 24 hours using a nutrient broth (NB) medium. Under these conditions, cell specific growth rate, $\square$ of about $0.16 \mathrm{hr}^{-1}$ was achieved. Studies also showed that C. artocarpi can also be grown using low cost agriculture-based resources such as liquid pineapple waste (LPW) or sugarcane bagasse to produce flexirubin [5].

One of the advantages of agricultural waste is that its content is rich with various types of sugar such as sucrose, glucose, and fructose [6] and contained substantial amounts of organic acids (citric, maleic, ascorbic), protein, phenolic compounds, and several trace elements which are essential for bacterial growth. Agricultural waste are also available in abundance for free (saving up to RM360 per run for $50 \mathrm{~L}$ scale production) and merely requires few pretreatment steps to purify the substrates prior to fermentation process [7]. Despite the advantages, flexirubin yield for cultivation using agricultural wastes as the main substrates were still much lower than the one using NB medium. Obviously, optimization of culture conditions and bioreactor operational parameters for cultivation using such subsrates must be done to further improve the yield of flexirubin.

Another important aspect in the production of flexirubin is the downstream processing and the purification steps. Flexirubin is a type of bioproduct that cannot be categorized as intracellular (inside the cells) or extracellular (released into solution) products. Such pigment is secreted extracellularly and it is not soluble in water but remains intact with the cells as a fragile pellicle covering (surrounding) the surface of the cells [8]. Given the state of the product, recovering of flexirubin would require one to first separate the cells-flexirubin component from the supernatant with subsequent liquid extraction step using organic solvent [8]. Different combinations of various unit operations can be utilized for recovering of flexirubin. Nevertheless, to optimize the entire downstream processing line for minimizing product losses whilst keeping the operation cost reasonably low is not so straight forward. Clearly, it would also involves a lot of experimental work merely to design and implement purification schemes that are repeatable, reliable and meet current good manufacturing practice (GMP) guidelines. On this basis, we believed the use of a process simulator software can be handy in optimizing the downstream processing steps and also as a tool to scale up process development in lab scale to manufacturing scale.

In this work, SuperPro Designer software - process simulator developed at Intelligent (Scotch Plains, NJ, USA) - is used to investigate suitable solution for purification of flexirubin at industrial scale. The work considered various purification schemes for flexirubin production from Chryseobacterium artocarpi using glucose as the main substrates. SuperPro Designer (SPD), is an integrated platform/program for process development, manufacturing process modeling, equipment sizing, economic evaluation, scheduling, and optimization; designed specifically for bioprocessing. The program has the capacity to setup a batch (or continuous) processes and provides data bases for chemicals, equipment and economical figures [9].

Once a conceptual flowsheet for an industrial scale flexirubin production plant is initialized including inputs on the reaction stoichiometric coefficients, and defining the raw material costs and revenues from the targeted product, the program calculated the overall cost for plant operation which takes into account equipment capital costs, operating costs, material costs as well as administrative and auxiliary costs. The program also comprehensively solved the material and energy balances for every unit operations chosen for the plant operation. Based on the reports provided by SPD, overall recovery yield and economic feasibility of various purification schemes of flexirubin production is evaluated. 


\subsection{METHODOLOGY}

\section{Simulation of Batch Production of Flexirubin}

The batch production of flexirubin was simulated based on the aim for batch production of $300 \mathrm{~kg}$ of violacein per annum. This assumption was based on a fact that commercial pigment based bioproducts from Sigma, Merck, etc. are generally sold in quantity of few milligrams. On this basis, it seems that it would not be logical to simulate an annual production of flexirubin for amount greater than few hundreds of $\mathrm{kg}$ per year. Figure 1 shows the process flow diagram displaying major equipment for inoculum development and production of flexirubin at 1000 litre scale. The simulation flowsheet was developed in SuperPro Designer v5.5.

In the inoculum development section, several stages of seed reactors were considered where volume for each inoculum was set for about $10 \%(\mathrm{v} / \mathrm{v})$ from the main production bioreactor. This is needed as to reflect actual practice where inoculum culture is typically $5-10 \%(v / v)$ of the main reactor in order to provide cells time adapt to new environment for cultivation. It starts with cell culturing of $C$. artocarpi strain at $30^{\circ} \mathrm{C}$ and $\mathrm{pH} 7$ using in a nutrient broth (NB) in a $1 \mathrm{~L}$ shake flask (working volume $=500 \mathrm{~mL}$ ). The fermented culture (biomass) was transferred to two subsequent seeding fermentation steps before serving as inoculum for the production reactor at $1000 \mathrm{~L}$ (working volume $=550 \mathrm{~L}$ ). The working volume of the seed fermenters are $5 \mathrm{~L}$ and $50 \mathrm{~L}$, respectively. Cell cultivation was carried out for 24 hours. Agitation was set at $200 \mathrm{rpm}$ and aeration was assumed in excess. Conditions applied for the process simulations were duplicated directly from the optimum conditions attained from the experimental work in lab scale $[5,8]$.

In each fermentation steps, stoichiometric balance for $C$. artocarpi fermentation were solved using the elementary component balance. The stoichiometric equation for the production of flexirubin is described in Equation (1) as follow:

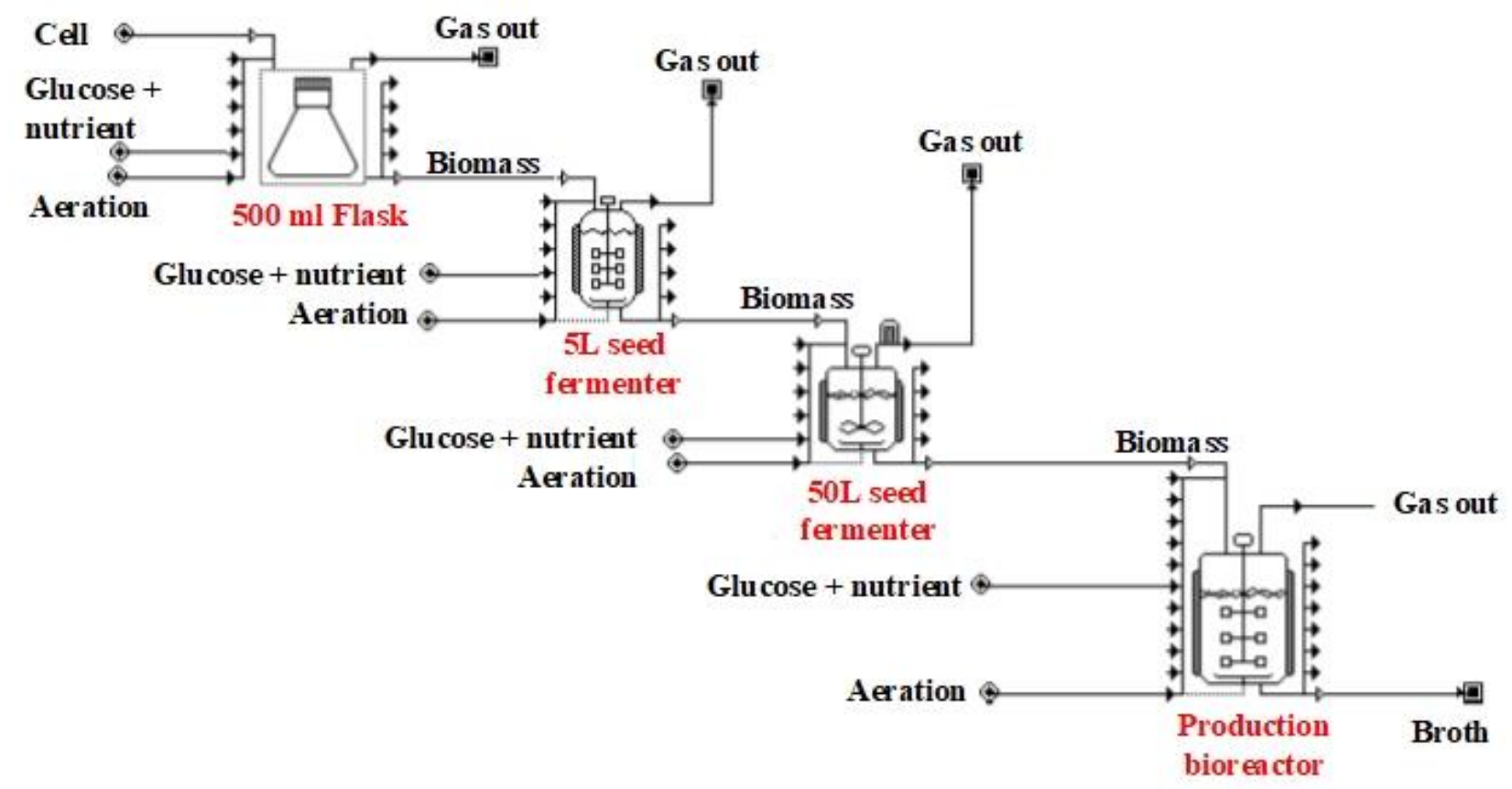

Figure 1 Simulation flowsheet for the inoculum development and the batch production of $300 \mathrm{~kg}$ per annum of flexirubin

\section{Designer v5.5.}

In the inoculum development section, several stages of seed reactors were considered where volume for each inoculum was set for about $10 \%(\mathrm{v} / \mathrm{v})$ from the main production bioreactor. This is needed as to reflect actual practice where inoculum culture is typically $5-10 \%(\mathrm{~V} / \mathrm{V})$ of the main reactor in order to provide cells time adapt to new environment for cultivation. It starts with cell culturing of $C$. artocarpi strain at $30^{\circ} \mathrm{C}$ and $\mathrm{pH} 7$ using in a nutrient broth (NB) in a $1 \mathrm{~L}$ shake flask (working volume $=500 \mathrm{~mL}$ ). The fermented culture (biomass) was transferred to two subsequent seeding fermentation steps before serving as inoculum for the production reactor at $1000 \mathrm{~L}$ (working volume $=550 \mathrm{~L}$ ). The working volume of the seed fermenters are $5 \mathrm{~L}$ and $50 \mathrm{~L}$, respectively. Cell cultivation was carried out for 24 hours. Agitation was set at $200 \mathrm{rpm}$ and aeration was assumed in excess. Conditions applied for the process simulations were duplicated directly from the optimum conditions attained from the experimental work in lab scale $[5,8]$. 
In each fermentation steps, stoichiometric balance for $C$. artocarpi fermentation were solved using the elementary component balance. The stoichiometric equation for the production of flexirubin is described in Equation (1) as follow:

$10 \mathrm{C}_{6} \mathrm{H}_{12} \mathrm{O}_{6} \quad$ (Glucose) $+8.82 \mathrm{C}_{11} \mathrm{H}_{12} \mathrm{~N}_{2} \mathrm{O}_{2} \quad$ (Ltryptophan) $+4.71 \mathrm{O}_{2}$ (Oxygen) $\rightarrow 1.18 \mathrm{C}_{43} \mathrm{H}_{54} \mathrm{O}_{4}$ (Flexirubin) $+1.75 \mathrm{H}_{2} \mathrm{O}$ (Water) $+18.24 \mathrm{CO}_{2}$ (Carbon Dioxide) $+88.24 \mathrm{CH}_{1.8} \mathrm{O}_{0.5} \mathrm{~N}_{0.2}$ (Biomass)

Based on the stoichiometric equation, for every 10 mole of glucose consumed, approximately 1.18 mole of flexirubin and 88.24 mole of biomass will be produced. By solving the stoichiometric equation for production of flexirubin, it allows us to estimate the amount of glucose (carbon source) and L-trytophan (nitrogen source) needed for the targeted amount of flexirubin per year. Key operating conditions for the simulation of flexirubin production in the $1000 \mathrm{~L}$ bioreactor is summarized in Table 1 and these conditions were applied in the simulation of the flexirubin batch fermentation processes to generate the composition of the fermentation broth. The composition of the fermentation broth is essential as it determines the feed properties for the subsequent downstream operation where it involves the separation and purification of flexirubin from the broth.

Table 1 Key operating conditions for the simulation of flexirubin production and the composition of the fermentation broth generated from the simulation

\begin{tabular}{|c|c|c|c|c|}
\hline $\begin{array}{l}\text { Stage/ Total } \\
\text { volume }\end{array}$ & $1 \mathrm{~L}$ & $10 \mathrm{~L}$ & $100 \mathrm{~L}$ & $\begin{array}{c}\text { Main } \\
\text { reactor }\end{array}$ \\
\hline $\begin{array}{l}\text { Working } \\
\text { volumes (L) }\end{array}$ & 0.5 & 5 & 50 & 550 \\
\hline $\begin{array}{l}\text { Reactor } \\
\text { operating } \\
\text { variables }\end{array}$ & \multicolumn{4}{|c|}{$\begin{array}{l}\mathrm{pH}=7,30^{\circ} \mathrm{C} \text {, agitation = } 200 \mathrm{rpm} \text {, } \\
\text { aeration = excess air (stock mixtures) }\end{array}$} \\
\hline $\begin{array}{l}\text { Growth } \\
\text { conditions }\end{array}$ & \multicolumn{4}{|c|}{$\begin{array}{c}\text { growth rate, } \mu=0.16 \mathrm{hr}^{-1} ; \text { Glucose = main } \\
\text { carbon source }\end{array}$} \\
\hline $\begin{array}{l}\text { Feed properties } \\
\text { of the } \\
\text { fermentation } \\
\text { broth to } \\
\text { downstream } \\
\text { operation }\end{array}$ & & & & $\begin{array}{c}{[X]=59.15} \\
\mathrm{~kg} \\
{[\mathrm{P}]=3.12} \\
\mathrm{~kg} \\
{[\mathrm{~S}]=5.01} \\
\mathrm{~kg} \\
\mathrm{H}_{2} \mathrm{O}(\mathrm{I})= \\
481 \mathrm{~kg}\end{array}$ \\
\hline
\end{tabular}
water content.

Downstream Processing Routes for Recovery of Flexirubin

Downstream operation for recovering of flexirubin involves two major steps. First, separation of flexirubinbiomass component from the fermentation broth and secondly, purification of the product. Three different processing routes were proposed for separation of flexirubin from the fermentation broth and the simplified process flow diagrams are shown in Figure 2. Flexirubin is immiscible in water and appeared on the outer layer of the cell biomass. So, as the first separation step, the general idea is to remove as much cell biomass as possible from the fermentation broth. As seen in all proposed separation schemes (Figure 2), a centrifugal unit and a dead-end filtration unit have both been proposed. Both units are a solid-liquid separator unit operation typically employed in industry for removal of cell biomass where recovery yield of the targeted cell biomass can reach as high $95 \%$ (or greater) - leaving other dissolved components in the filtrate. In the subsequent step i.e. after removal of cell biomass, flexirubin is recovered using the liquid extraction method. In the present work, it is proposed that the extraction step was carried out using either the centrifugal extraction unit or the classical mixer and settler extraction equipment. Acetone was chosen in both units as the organic solvent for the extraction. The final step in the downstream operation is the purification step where actions are needed to produce a stream containing highly purified flexirubin component. For this purpose, a spray dryer unit was proposed. Alternative solution using a rotary evaporator was also included for comparison. Both are viable solution for efficient removal of solvents from the flexirubin-acetone mixture by evaporation. This is because separation can merely be done based on the differences in the components boiling point. It was found that the boiling point of flexirubin $\left(797^{\circ} \mathrm{C}\right)$ is much greater than the boiling point of acetone which is only at $56^{\circ} \mathrm{C}$.

a)

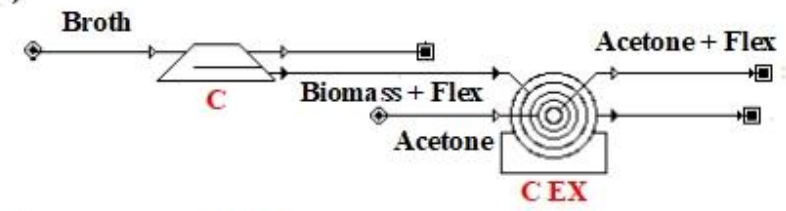

b)

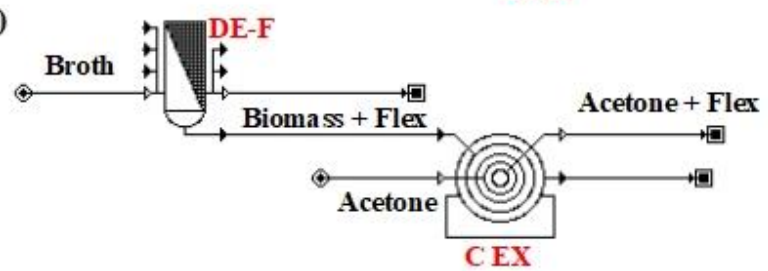

c)

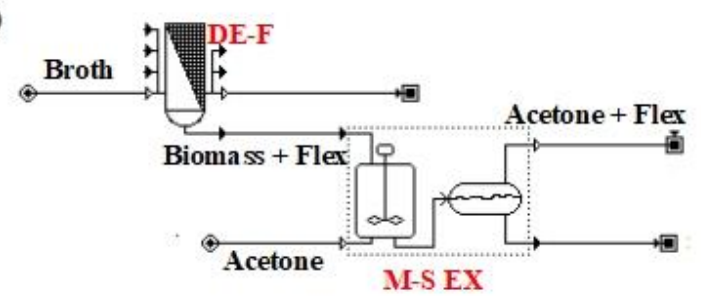

Figure 2 The process flow diagrams for the separation of flexirubin from the fermentation broth. a) Centrifuge (C) and centrifugal extraction (C EX) route. b) Dead-end filtration (DE-F) and centrifugal extraction (C EX) route. c) Dead-end filtration (DE-F) and mixer-settler extraction (M-S EX) route 
In the simulation work, key operating variables that influences the process recovery yield, and operational cost were identified and optimized. Investigation was performed separately for each unit operations and input parameters that were specified in the simulation work for the downstream operation is summarized in Table 2. The process simulator (SuperPro Designer $\AA$, Intelligen, Inc., USA) quantified the process characteristics, and equipment parameters of each major equipment for the specified operating scenarios. Once this is done, full simulation results can be viewed. Simulated outputs included results on materials output compositions and amount, equipment size, process costing and scheduling information. The information obtained was used as basis of discussion in determining the best downstream operation routes based on overall yield and operation and equipment costs.

Table 2 Key input parameters for the simulation of downstream operation

\begin{tabular}{ll}
\hline Unit operations & $\begin{array}{l}\text { Input (adjustable) operating } \\
\text { variables }\end{array}$ \\
\hline Centrifugation unit (C) & $\bullet \begin{array}{l}\text { Feed to concentrate } \\
\text { ratio }\end{array}$ \\
& - Max throughput \\
& Processing time
\end{tabular}

\subsection{RESULTS AND DISCUSSION}

Three different separation schemes were proposed for recovery of flexirubin from the fermentation in $1000 \mathrm{~L}$ bioreactor. In the bioreactor operating conditions mild aeration and agitation rates were chosen for the simulation work as high aeration and agitation rates may cause a serious shearing effects that could lead to cell death and eventually reduction in metabolite production [10]. Flexirubin recovery yield and the operational costs of the proposed unit operations were estimated by the simulation model. Figure 3 shows the results attained from the simulation model for the centrifugal unit. The simulation model was performed at maximum unit throughput of about $100 \mathrm{~L} / \mathrm{hr}$ and by assuming at least $95 \%$ of cell biomasss and flexirubin will be recovered at the end of the process. As shown in Figure 3(a), only the water content reduces as ratio of feed to concentrate increases whilst the amount of other components remains unchanged. This was expected and consistent with what was achieved in our lab and pilot scale experiments [11]. The results attained seemed logical because by increasing the feed to concentrate ratio, one actually increases the rotational speed of the centrifugal unit at constant processing time or vice versa. In theory, cells (or at least most organic constituents in cells) are denser than water $\left(\rho>1 \mathrm{~g} / \mathrm{cm}^{3}\right)$ [12]. Anything that has a density greater than that of water will sediment. During centrifugation, cell biomass in suspension are compacted into a pellet and therefore, by increasing the feed to concentrate ratio it will somewhat boost the sedimentation rate of the cell biomass while concurrently remove considerable amount of water in the process.

Our investigation was first based on a maximum unit throughput of $100 \mathrm{~L} / \mathrm{hr}$. Interestingly, when the limit for the unit throughput was increased to $200 \mathrm{~L} / \mathrm{hr}$ (i.e. two folds more), not only it shortens the processing times significantly by it would also reduce the number of centrifugal unit needed to facilitate the separation of cell biomass from the fermentation broth. At the same processing time of $180 \mathrm{~min}$, at 200 $\mathrm{L} / \mathrm{hr}$ unit throughput, only one centrifugal unit is required and not two when unit throughput was set at $100 \mathrm{~L} / \mathrm{hr}$. Operation cost also decreased by nearly halves i.e. drop from \$53 400 down to \$27 200 per batch. Obviously, capital cost for the equipment increases as higher throughput mean larger unit but result shows that the capital cost was only slightly increased (less than 10\% increase was recorded) when higher throughput unit was used. Present literature shows that centrifugal unit in industry does indeed has the capacity to handle $200 \mathrm{~L} / \mathrm{hr}$ of feed [13]. In centrifugation operation, despite a high recovery yield for cell biomass (and flexirubin in this matter), the concentrated biomass will always in a form of slurry due to the presence of a small amount of water. This is to be expected as it is not logical to completely remove the water from the broth via centrifugal unit. Similar output was also evident in our lab work [11]. 

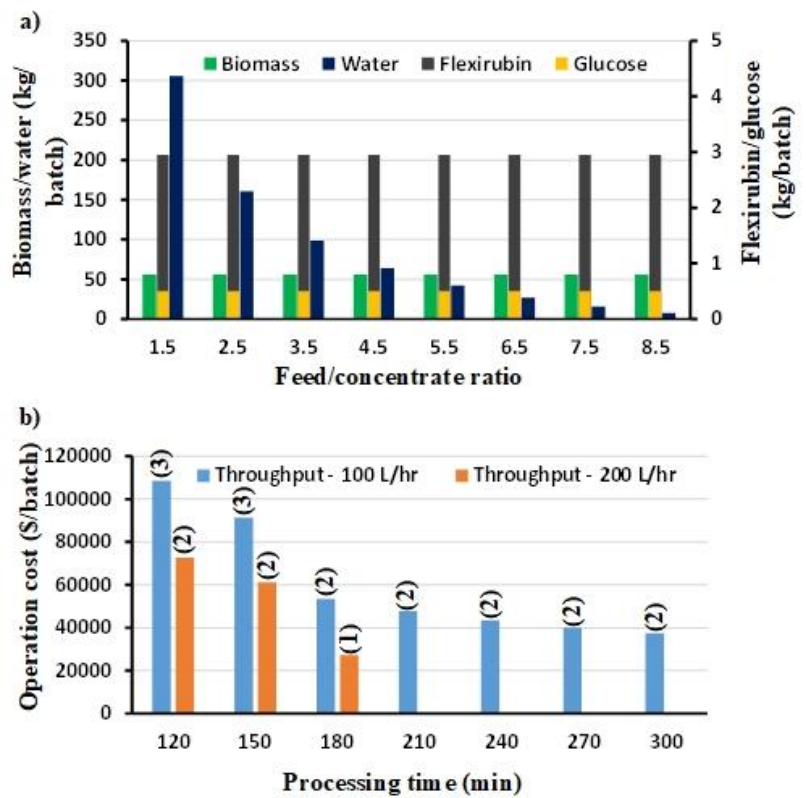

Figure 3 a) Reduction of water content in centrifugal unit as feed to concentrate ratio increases. b) Comparison of operating cost at difference processing times for centrifugal unit between operation throughput of $100 \mathrm{~L} / \mathrm{hr}$ and $200 \mathrm{~L} / \mathrm{hr}$. Quantity of centrifugal units needed is shown in the parenthesis

Alternative solution for removal of cell biomass from the fermentation broth using a dead-end filtration unit was also evaluated. Figure 4 presents the comparison of data between the centrifugal and the dead-end filtration unit in terms of cell biomass recovery yield and operational costs. Similarly to centrifugal unit, recovery yield of the dead-end filtration unit is also relatively high in which at least $95 \%$ or greater of cell biomass was retained. In deadend filtration unit, separation is merely based on the difference of the cell biomass the size of the filters pore.

In the simulation work, a high ratio of product removal and desired particle concentration in retentate were set due to the fact that the average size of most bacteria (presumably including $C$. artocarpi) is between 0.2 and $2 \mu \mathrm{m}$. Since filter pore size as small as $0.1 \mu \mathrm{m}$ can be installed in most industrial scale dead-end filtration unit, achieving a high degree of cell biomass separation is indeed possible. Despite a high recovery yield, it seemed that the operational cost for dead-end filtration unit is much greater than that of centrifugal unit - at least by 4 folds higher. On contrary, the capital cost for the dead-end filtration unit ( $\$ 608000$ ) is however much lower compared to the capital cost of the centrifugal unit operation (\$2849 000). This is probably due to a simpler setup and separation mechanism of deadend filtration unit. Clearly, compromise have to be made for a more economical yet efficient solution for cell biomass removal. Centrifugal unit probably offers a shorter processing times (i.e. in the range of few minutes) but filtration unit technically do not impose any damage to cells whilst warrant a high recovery rate.

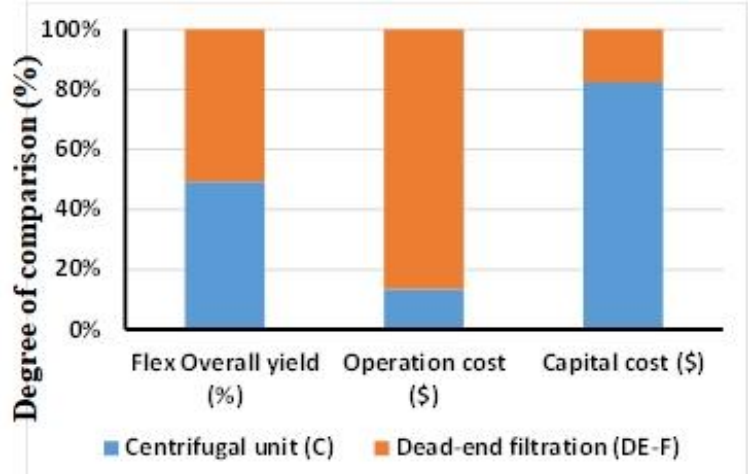

Figure 4 Comparison between centrifugal and dead-end filtration unit operation performance based on the recovery yield and operational costs

Figure 5 illustrates the results of the operation of centrifugal extraction unit for retrieving of flexirubin from the cell biomass mixture. The unit was installed immediately after the solid-liquid separator unit where the cell biomass-flexirubin mixture was considered as the heavy phase whilst acetone was considered as the extracting solvent in the light phase feed stream (Figure 2). Both feed streams enter the mixing zone counter-currently in the central region of the unit where liquid-liquid dispersion takes place and extraction occurs as flexirubin is transferred from one phase into the other. In the simulation work, the relative solubility constant (Kvalue) was set to 1 since flexirubin is miscible only in the organic solvent (acetone) and highly unlikely it will dissolve in water. As shown in Figure 5(a), it can be seen that as the amount of acetone increases, recovery yield of flexirubin increases as well. It escalates significantly when the quantity of acetone was raised from $50 \mathrm{~kg}$ to $150 \mathrm{~kg}$ but did not show much of a difference when amount of acetone used was $200 \mathrm{~kg}$ or greater.

Clearly, by increasing the amount of acetone, operation cost proportionally increased due to rising cost of acetone usage per run. Interesting, it was found that by increasing the number of theoretical stages for the centrifugal unit, product recovery rate improved at much better rate. Capital cost was only slightly increased while the operational cost remained the same $1 \sim \$ 15000$ per batch for every $150 \mathrm{~kg}$ of acetone). It can be discussed here that perhaps mixing conditions and separation operations within the multistage centrifugal unit itself promotes a better mass transfer for the transfer solutes from the feed solution to the carrier solvent and thus, warrants a better recovery yield.

Extraction of flexirubin from the cell biomass mixture could also be performed using a classical mixer and settler extraction unit. Contrary to the centrifugal extraction unit, in this mixer-settler 
extraction unit, both extracting solvent (acetone) and the aqueous cell biomass mixture was first mixed in a stirred tank and then followed by sedimentation of particles to remove the heavy compounds (cell biomass). Based on the simulation results, under similar conditions as applied in the centrifugal extraction unit, recovery yield increases as the amount of acetone increases. Interestingly, operation cost somehow did not increase by much. It can be presumed that lower operational cost probably because of the separation of light and heavy phase occurred by gravity and not through excessive centrifugal force. Losses of acetone during extraction is also lower which in turn increases contact times and better recovery yield during mixing period. The simulation results also show that increasing of the number of theoretical stages for such classical mixer-settler will caused the operation cost to increase nearly proportional to the number of stages. This is probably because for mixer-settler unit of multiple stages, mixing and settling chambers are placed at alternating ends for each stage. Clearly, pumps and stirrers are needed for such operation consequently increases electricity usage and thus, overall operation cost. Although the operation cost did increase as the number of stages increases, overall operation cost with 4 theoretical stages $1 \$ 13$ 600 ) is still lower than that of centrifugal extraction unit (\$16 000).
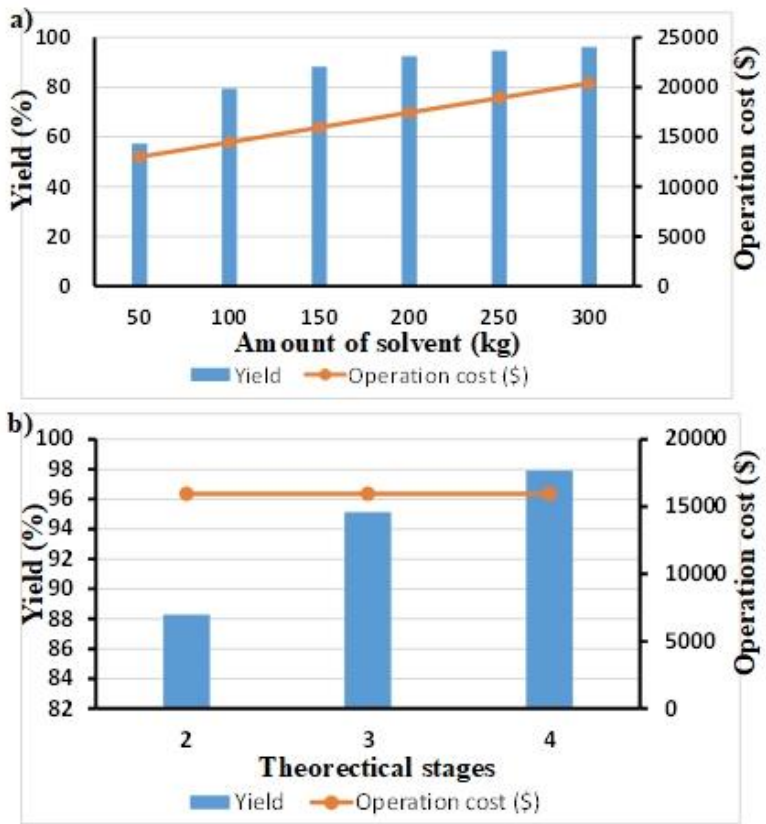

Figure 5 Simulation results for centrifugal extraction unit. a) Increasing of the amount solvent used improve recovery yield and increases operation cost. b) Effect of the number of theoretical stages on the recovery yield and operation costs

Data attained from the optimization steps of each unit operation involved in the downstream operation were utilized and reused. Comparison was made on different downstream routes (Figure 2) for annual production of $300 \mathrm{~kg}$ of flexirubin where basis operating time of 330 days per year (7920 hr) was used in the model. Simulated overall recovery yield of flexirubin, operational cost and capital investment on equipment for each proposed downstream processing routes is summarized in Table 3 . It was observed that all proposed downstream processing routes is capable of achieving a high degree of flexirubin recovery yield i.e. at least $94 \%$ (or greater). Results generated by the software indicated that - at the recommended operating conditions; product loss was minimal in each separation steps. From the economics point of view, estimated operation cost for route consisting of centrifugal and centrifugal extraction unit are the lowest compared to the other proposed routes. The estimated operational cost (route 1) was \$37 583 per run which is nearly 5 times lower than the other two proposed routes. Shorter processing times of the centrifugal unit for recovery of the cell biomass - flexirubin mixture from the fermentation broth was the bottleneck for this assessment. Shorter processing routes literally means lower labor cost. Utility cost e.g. electricity and usage of water for cleaning during post operation phase could also contributed to the increase of unit operational cost.
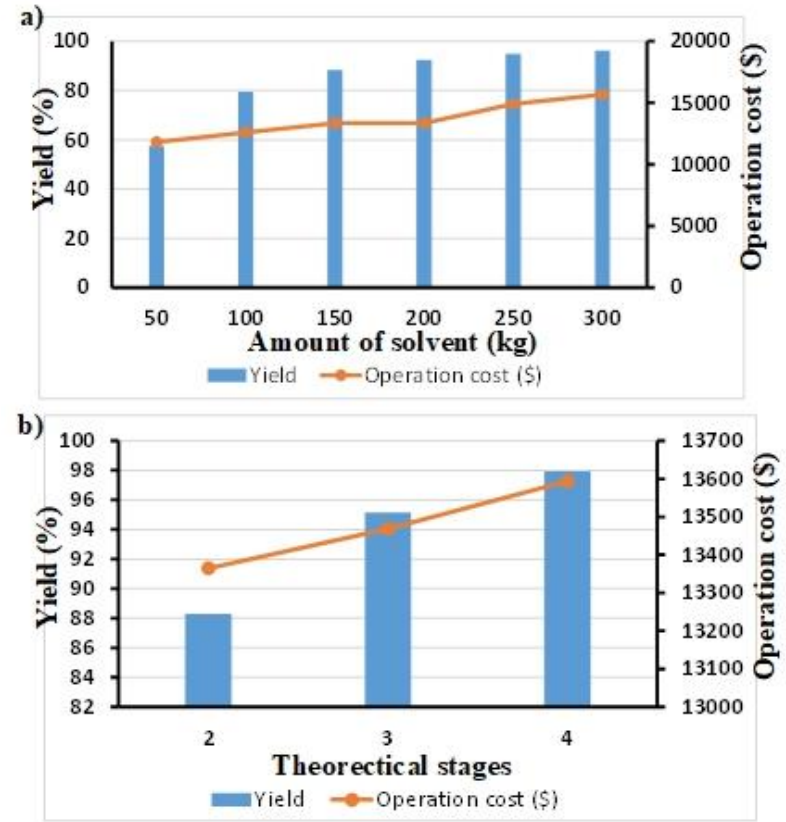

Figure 6 Simulation results for mixer and settler extraction unit. a) Increasing of the amount solvent used slightly improve recovery yield and increases operation cost. b) Effect of the number of theoretical stages on the recovery yield and operation costs

Cleaning a filter and performing back-wash operation prior to facilitate the next of feed is indeed time consuming compared to time needed for 
cleaning of cells residues within a centrifugation unit. Contrary to the results of the operational cost per batch, capital investment needed for purchasing of equipment in the route involving the use of centrifugal unit is at least 3 folds more than the ones consisting of dead-end filtration unit. Detailed breakdown of the capital cost (data not shown) shows that design complexity of the centrifugation unit itself caused the increase of the rate for process piping, instrumentation (valve, pumps and controller) and contractor fees. This however was not the case for dead-end filtration unit. Simpler design and smaller foot-print reduces overall capital cost needed for purchasing of the equipment.

Table 3 Comparison of downstream operation routes in terms of overall yield, operation cost and capital cost

\begin{tabular}{lccc}
\hline & $\begin{array}{c}\text { Route 1 (C + } \\
\text { C EX) }\end{array}$ & $\begin{array}{c}\text { Route 2 (DE- } \\
\text { F + C EX) }\end{array}$ & $\begin{array}{c}\text { Route 3 (DE-F } \\
\text { + M-S EX) }\end{array}$ \\
\hline $\begin{array}{l}\text { Flexirubin } \\
\text { overall yield } \\
(\%)\end{array}$ & $94 \%$ & $96.9 \%$ & $96.9 \%$ \\
$\begin{array}{l}\text { Operation } \\
\text { cost (\$) per } \\
\text { batch } \\
\begin{array}{l}\text { Capital cost } \\
\text { (\$) }\end{array}\end{array}$ & $\$ 37583$ & $\$ 190781$ & $\$ 188417$ \\
\hline
\end{tabular}

Earlier findings provided information for determination of the most efficient and economical for the recovery of flexirubin from the fermentation broth. The final step in the downstream operation of flexirubin is the purification stage where we compared capital and operational cost between a rotary evaporator and a spray dryer unit. Based on the simulation results (as illustrated in Figure 7), it shows that the operational cost for both units are comparable i.e. at approximately $\$ 26-27 \mathrm{k}$ per batch. This is relatively low. A small amount of flexirubin as feed on those equipment (i.e. merely few kilograms were recovered per batch) was probably the reason why only a small quantity of hot air and/or steam is needed for the drying purposes in spray dryer and rotary evaporator. This in turn reduces overall operation cost. Interestingly, despite much a simpler drying operation capital investment needed for installation and commissioning of an industrial scale rotary evaporator unit is expensive.

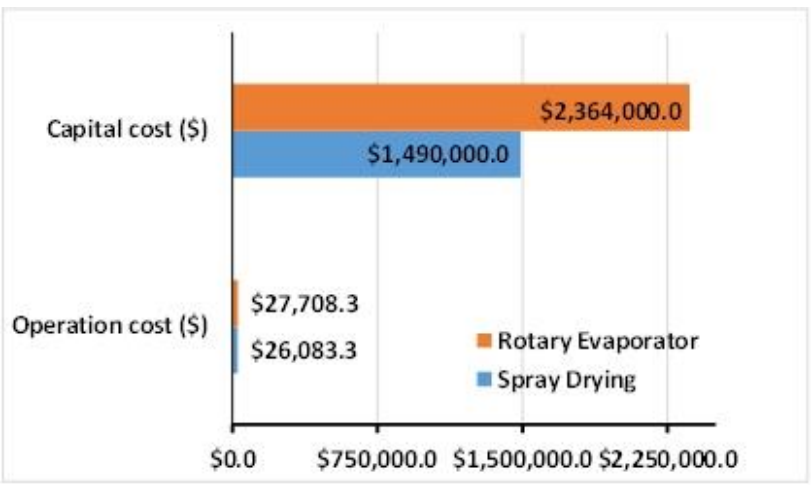

Figure 7 Comparison of operation and capital cost between rotary evaporator unit and a spray dryer unit for purification of flexirubin

Simulated results indicated that increased in the capital cost of rotary evaporator unit was mainly due to process piping (steam, cold water and electricity) and instrumentation. Clearly, spray dryer unit would be preferable for the final purification step of the downstream operation for recovery of flexirubin. Plus, spray dryer has the flexibility in tailoring the properties of the final powder of targeted product (in this case flexirubin) and much more suitable for food grade product.

\subsection{CONCLUSIONS}

SuperPro Designer software (Intelligen, Inc., USA) was successfully utilized to investigate suitable downstream operation (separation and purification) for recovery of flexirubin. Simulation was executed for annual production of $300 \mathrm{~kg}$ of flexirubin where basis operating time of 330 days per year $(7920 \mathrm{hr}$ ) was used in the model. Simulated results suggested that capital investment cost for purchase of equipment needed for the downstream operation can be significantly reduced by excluding a centrifugal unit. A significant cost reduction by at least $40-50 \%$ can be achieved if such selection is made. It is believed that sufficient economic evaluation has been made on the conceptual flowsheet proposed using SuperPro especially considering the absence of several essential details. Impact on the economics of flexirubin production will of course can be further improved and it definitely depends on selected flowsheet and inclusion of both minor and major unit operations. 


\section{Acknowlegement}

This project was funded by the Fundamental Research Grant Scheme of Minister of Higher Education of Malaysia (R.J130000.7851.5F230).

\section{References}

[1] Venil, C. K., Khasim, A. R., Aruldass, C. A., \& Ahmad, W. A. 2016. Microencapsulation of Flexirubin-Type Pigment by Spray Drying: Characterization and Antioxidant Activity. International Biodeterioration and Biodegradation. 113: 350-356.

[2] Kim, S. K. 2013. Marine Biomaterials: Characterization Isolation and Applications. CRC Press, Taylor \& Francis.

[3] Venil, C. K., Zakaria, Z. A., Usha, R., \& Ahmad, W. A. 2014. Isolation and Characterization of Flexirubin Type Pigment from Chryseobacterium sp. UTM-3T. Biocatalysis and Agricultural Biotechnology. 3(4): 103-107.

[4] Suhaimi, S. N., Hasan, S., Shamsuddin, S. M., Ahmad, W. A. \& Venil, C. K. 2018. Statistical and Nature-inspired Metaheuristics Analysis on Flexirubin Production. International Journal of Advances in Soft Computing and Its Applications. 10(20): 5 0-70.

[5] Aruldass, C. A., Aziz, A., Venil, C. K. Khasim, A. R., \& Ahmad, W. A. 2016. Utilization of Agro-Industrial Waste for the Production of Yellowish-Orange Pigment from Chryseobacterium artocarpi CECT 8497. International Biodeterioration and Biodegradation. 113: 342-349.

[6] Jusoh, N., Othman, N., Idris, A., \& Nasruddin, A. 2014 Characterization of Liquid Pineapple Waste as Carbon Source for Production of Succinic Acid. Jurnal Teknologi (Sciences \& Engineering). 69(4): 11-13.
[7] Conesa, C., Seguí, L., Laguarda-Miró, N., \& Fito, P. 2016. Microwave-assisted Alkali Pretreatment for Enhancing Pineapple Waste Saccharification. BioResources. 11(3): 6518-6531.

[8] Aruldass, C. A., Dufossé, L., \& Ahmad, W. A. 2018. Current Perspective of Yellowish-orange Pigments from Microorganisms- A Review. Journal of Cleaner Production. 180: 168-182.

[9] Vacharakis, N., Louizaki, A., Charalambous, C., Rafaelides S., Koulouris, A. 2018. Techno-Economic Evaluation of $\beta$ Cyclodextrin Production from Cassava Tubers. Proceedings of FOODSIM'2018, Ghent, Belgium.

[10] Zhou, Y., Han, L. R., He, H. W., Sang, B., Yu, D. L., Feng, J. T., \& Zhang, X. 2018. Effects of Agitation, Aeration and Temperature on Production of a Novel Glycoprotein gp-1 by Streptomyces Kanasenisi zxO1 and Scale-up based on Volumetric Oxygen Transfer Coefficient. Molecules. 23(1): $1-14$.

[11] Venil, C. K., Zakaria, Z. A., Usha, R., \& Ahmad, W. A. 2014 Isolation and Characterization of Flexirubin Type Pigment from Chryseobacterium sp. UTM-3T. Biocatalysis and Agricultural Biotechnology. 3(4): 103-107.

[12] Li, L., \& Pagilla, K. R. 2017. Biomass Density-function Relationships in Suspended Growth Biological Processes A Critical Review. Water Research. 111 (April): 274-287.

[13] Seyfang, B., Klein, A., \& Grützner, T. 2019. Extraction Centrifuges-Intensified Equipment Facilitating Modular and Flexible Plant Concepts. Chem Engineering. 3(1): 17.

[14] Roussos, A., Misailidis, N., Koulouris, A., Zimbardi, F., Petrides, D. 2019. A Feasibility Study of Cellulosic Isobutanol Production - Process Simulation and Economic Analysis. Processes. 7(10): 667. https://doi.org/10.3390/pr7100667.

[15] Koulouris, A., G. Aroutidis, D. Vardalis, P. Giannoulis, V. Karakosta. 2015. Enhancing Food Engineering Education with Interactive Web-based Simulations. International Journal of Food Studies. 4. 